\title{
worldview
}

\section{PRINCIPLES AND POLITICS: IHE PARADOX OF THE '64 CAMPAIGN}

The present presidential campaign differs significantly from those of the last several decades. Senator Goldwater is quite correct in regarding bis candidacy as a radical attack on the policies of the present administration and by implication, therefore, on the bipartisan foreign policies of recent administrations. Certainly his familiar slogan-"a choice, not an echo"-means exactly that to a considerable number of his supporters and his opponents.

The present campaign should, then, be a time of confrontation. Opposing principles, policies and programs should be meeting in a head-on clash, casting off sparks that not only heat up the political atmosphere but illuminate the issues. On the whole, this has not taken place. Amid the intermperate charges that are being hurled around, amid the strong epithets and loose accusations there have emerged several large areas that could be the focus for sensible debate and discussion, e.g., foreign policy, big government, civil rights. Yet only a few concrete, particular points have actually served as lightning rods, and the discussion on these points has soon sputtered out.

This campaign then presents us with a large paradox: where there should be a sharp confrontation of strongly differing views there is a muffled, confused and frequently mean disorder; where one anticipated strong enthusiasm and exciting partisanship there is general apprehension, disquiet, and, increasingly, boredom.

Part of the reason for this paradox was suge gested by the unsettling sermon of the Very Reverend Francis B. Sayre; Dean of the Protestant Episcopal Cathedral in Washington, D.C.

"This summer we beheld a pair of gatherings at the summit of political power, each of which was completely dominated by a single man; the one a man of dangerous ignorance and devastating uncertainty, the other a man whose public house is splendid in its very appearance but whose private lack of ethics must inevitably introduce termites at the very foundation."

One need not agree with Dean Sayre's perceptions-or his conclusion that the voters have only a "sterile choice"-to recognize that he has isolated the most persistent charges that are being exchanged in this campaign.

Senator Goldwater and his supporters consistently try to portray Johnson as a political wheeler-dealer without principles. Beyond that they suggest that there has been a general national drift away from principles and morality, a drift for which the federal government and its chief executive are somehow responsible. It is only the lack of moral fiber, they contend, which prevents this strong nation from imposing its will, its concepts of freedom and justice, on the dangerous, the recalcitrant, the disorderly.

This is why we give way to communism abroad and fail to quell riots and stem crime at home; this is why we look to the federal government rather than to the state government or, preferably, to private initiative to solve problems of poverty, unemployment, illness. What is needed is a sincere man, an honorable man, a principled leader. This view is frequently put forth by Goldwater, who recently formulated it thus: "Johnson has no principles upon which to base his programs. The programs are solely political." And by a group of businessmen who say that his supporters "are for Barry Goldwater because he puts principle ahead of politics."

The opponents of Goldwater-who include but are not to be completely identified with the supporters of Johnson-are frequently willing to allow that Goldwater is a man of principles. He is, they grant, in favor of order, justice, freedom, peace and prosperity; he is in favor of greater armaments and lesser taxes; he is opposed to segregation and in favor of states rights; he is against crime. But what, they ask, are his policies. What particular programs does he recommend? Why 
doesn't he, if he can, say specifically how he would handle the crisis in Vietnam, the situations in East Germany and Cuba? What would he do for South America? And with President de Gaulle? How would he curb violence in the streets, and how would he suggest that the poor and unemployed; the old and sick, minister to their own needs?

It is fine to declare that one has principles but it is necessary to relate them to particular programs. And it is in the area between principles and programs that there is needed all the intelligence, and experience, shrewdness and wisdom that one can muster. For ignorance and misplaced certitudes in the implementation of policies are not only wasteful but dangerous.

It is because these are the main charges in the campaign that the debate is unsatisfying. For we do not see one set of articulated principles clashing with another, or one developed program with another. We see one side claiming that it should be elected because it knows what to do to develop a great society and the other side claiming priority because it is on the side of righteousness and morality. And neither side attempts to show the ineluctable relation between principles and policies.

Johnson has attempted to show himself, in contrast to the Senator, as an experienced, balanced politician who understands the needs of the people and can fulfill many of them, who understands the dangers of the international scene and can avoid them. While he has not excited enthusiasm or affection he has widespread support. Goldwater has tried to show himself, in contrast to the President, as a principled man above politics. But for a politician to rise above politics is like a bishop rising above religion. This odd stance has gained him some enthusiastic followers, but not the widespread support that makes a President.

If the present polls are accurate they indicate not that the American public is indifferent to the relation between principles and policy, between office-holder and the democratic process; instead, they indicate that the American citizen in his political pragmatism would rather infer a man's principles from his political actions than attempt to deduce his political program from his declared high principles.

\section{In the magaxines}

We have come a long way from the days when "the great shelter debate provided moments of ghoulish humor as theologians debated the precise conditions that would justify the shooting of a trespassing neighbor attempting to force entry into one's private shelter." C. W; Grifin warns in Liberation magazine, "civil defense today is no laughing matter."

Mr. Griffin, described by the editors as "an engineer" who "testified last spring before the House Armed Services Committee against the proposed fallout shelters incentives bill," contributed his views on the civil defense program in an article titled, in puining fashion, "The Offense of Civil Defense" (September).

"Placed under the Defense Department three years ago, at least partly to exploit that organization's infallible techniques for extracting billions from Congress, he writes, the new Office of Civil Defense (OCD) is aiming high." Griffin then marshalls evidence to indicate that ${ }^{\alpha}$ the case for fallout shelters" which the OCD presents to the Congress and to the nation is "a weird concoction of doublethink, inconsistency, and complacency, all the more remarkable for requiring the expenditure of so much time, effort and money.".

He finds "no indication, for example, that the Pen- tagon war-games experts are adapting the civil defense program to the changing character and increased potential of any enemy attack." He cites the writings of "several independent experts". who "believe that air bursts, which maximize fire and blast damage while producing no local fallout, are the most likely kind of attack on our popular metropolitan areas" while the "OCD persists in focusing on the fallout hazard."

Indeed, says author Griffin, "far from constituting the extravagant life-saving insurance guaranteed by the OCD, the fallout shelter program could conceivably increase fatalities in a thermonuclear attack" where there has been "a change in enemy bombing strategy." The "Pentagon assurances that there is no prospect of obsolescence in a fallout shelter system display a Miginot-line complacency nothing less than incredible in an age that has seen such vertiginous progress in weaponry."

"It is significant that the revolt against traditional approaches to the study of international affairs has taken place outside the United States," J. W. Burton has written in the September issue of The Journal of Confllict Resolution. In the U.S., where "in-

2 worldview 